\title{
PROFESSOR BRUCE'S LECTURES AT THE UNIVERSITY OF CHICAGO.
}

\author{
By EDMUND BUCKLEY, PH.D., \\ The University of Chicago.
}

Professor Alexander Balmain Bruce, D.D., of the Free Church College, Glasgow, has just finished a course of lectures at the University of Chicago upon Apologetics. The appreciation of the work done by him was intimated in an ovation which was tendered him at the close of the final lecture. On that occasion Dr. G. W. Northrup, the reverend and revered Head Professor of Dogmatic Theology in the University rose to recognize the indebtedness of the University to its distinguished lecturer, saying that his words had proved illuminating, emancipating, invigorating, and wonderfully suggestive in these days of transition, and that there was no living man with whom he stood in closer sympathy.

Professor W. C. Wilkinson then rose to extol the freedom of handling, which had indeed proved emancipating, and at the same time the religious spirit amounting to an unction from the Holy One, which had distinguished the lecturer. Last, the Rev. E. F. Williams stated that never had he heard a lecturer so many times in succession from whom he had learned so much. The sequent, loud and prolonged applause showed how representative these expressions had been. The eminent lecturer, the only uncomfortable man present, expressed himself as equally grateful and humble, believing that a little insight and a little sincerity had drawn so many hearers when eloquence alone must have failed.

These remarkable testimonies, not to mention the high repute of the lecturer, call for a summary in these columns. Lack of space precludes notice in this issue of the lectures devoted to evolution and agnosticism.

The Historical Foundations of Christianity.-The influence of faith upon the sacred record has been greatly exaggerated, as appears from the following considerations: (I) The theory of two parties in the primitive church should be revised by viewing them as a fact-party and an idea-party, the former of which should be named the Christ-party. (2) Luke's introduction to his gospel shows that even within the Pauline idea-party were some possessed by the historic spirit. (3) Peter's frank, impulsive, often inconsistent nature, while making him a weak apostle, made him a first-class witness, and his traits reappear in Mark's Gospel. (4) The existence of so many gospels favors historicity.

These considerations tend to check skepticism, though they do not solve all doubts. My bias on ethico-religious grounds is towards historicity.

289 
Canons of historicity are: (1) Synoptical agreement. (2) When absence is explicable by some known bias. (3) When the singly attested item stands in agreement with or complement to other well attested items. (4) When the record suits the circumstances. (5) When unique religious genius is manifest.

Omitting the miraculous element in Christ's experience, we may consider the miracle in his healing ministry as follows: (I) Did it happen? (2) Was it really miraculous? (3) What is its present value?

The healing ministry really happened, for: (I) It was so associated with preaching that the popular mind considered Jesus a healer. (2) Eleven miracles are recorded by all synoptists. Thus the primitive apostolic gospel included miracles, which therefore did not originate in later mythic fancy. (3) Miracles are so interwoven with didactic material that they cannot be eliminated without destroying the latter. For example, most of the utterances of Jesus about faith were connected with miracles. (4) The miracles made impressions of wonder and occasioned theories as to their source, $e_{\text {. }} g$., in Beelzebub. (5) The healing ministry was original with Jesus, and therefore not demanded by precedent.

The problem whether the miracles were strictly such is not vital to faith. Where the old apologetic made signs a proof of revelation, the modern makes them a part of it. Whatever the nature and source of the healing power, it was certainly extraordinary. Do you smile at this view ? Then offer a better one in its place. To say that Jesus wrought miracles because God may be worth very little to one's mind. Better wonder over them.

While the value of the miracles was formerly overestimated, the present tendency is towards an opposite extreme. They are important as implying the value of the body, and therefore as a protest against asceticism, and also as an example of philanthropy. However, such alleged miracles as the rising of many dead at the crucifixion, and indeed all cases of rising from the dead may be critically examined.

Modern criticism thinks it finds in the history of the passion some baseless reports and legends based on Old Testament texts. However, granting all that Brandt claims, enough is left to give tragic significance and even serve as theological basis. The undoubted bias of the evangelists to identify Jesus as the Messiah formed a temptation to manufacture facts, yet it is much more probable that facts suggested texts in themselves obscure.

The passion history has great didactic value in that: (I) It exemplifies the destiny of righteousness in this world, and thus teaches faith. (2) It is the story of love. (3) It encourages hope for the world. (4) It secures to Christ's death its rightful place in human thought, namely above that sacerdotalism which makes the Lord's Supper more than a memorial feast, and that dogmatism which subordinates the event to some speculative theory. Further, the passion history has value as a record of the satisfaction given for sin. 
Historical Christianity as a Test of Ecclesiastical Christianity. - Ecclesiasticism claims that the church, as a normal evolution, has preserved all vital truth, and that God is with it now as in the first centuries. But does not the purity of these centuries point back to something purer? And has not the church often fallen into need of reform, which was effected by those who heeded the historic Christ? The church's idea of God is not even yet Christianized, and it has looked to Paul rather than Christ for its doctrine of salvation. Finally, one who taught the fatherhood of God and the brotherhood of man could not possibly have originated Romanism.

Historical Christianity as a Test of Philosophical Christianity. - Philosophy prefers ideas to facts, and thus threatens danger when as now it becomes a Zeitgeist. But fortunately at the same time the general acceptance of the evolution theory has brought history to its rights. The history of a thing is the thing. Philosophy must not despise religious crises and personalities, whence we may cherish the memory of Jesus. Whatever transformations Christianity may undergo, it must ever owe most to Jesus, who first taught free communion with God as Father, and to regard men as his sons.

The weak side of the philosophical school is surrendering at discretion to negative criticism. Thus did the late Professor T. H. Green, of whom I must speak with profound respect as a leader of noble young men. Nor do I condemn his position, considering that it was taken under the great destructive influence of Strauss. But this attitude need not be made permanent.

Where Green offered us ideas, Brandt - the present Strauss in point of destructiveness - presents us with ideals. Truth or fiction, what does it matter? We possess the picture in Jesus, the ideal of human goodness, and that is enough. But we must ask Brandt, will this merely ideal factor really help us to live a noble life, or does not it rather reduce goodness to a poet's dream? Does not the history of the Netherlands owe its power to the fact that the heroism was actually there?

Again, Professor E. Caird and some others claim that no individual-not even Christ - can adequately represent the union between the divine and human. Then was not the ethical so realized in Christ that no better realization is possible? The catholic church says it was. It is true that this perfect realization cannot be demonstrated from the gospels, but they point that way, and surely Jesus is likely to retain his preëminence in the moral sphere. His actions can, of course, be translated into their modern equivalents.

The beginning of faith is a mystery in any case, and may come through gospel, church, or philosophy, but its nourishment must be sought chiefly in the gospels. Our intuitions need support, and our inferences confirmation, and they can find them in the gospels. Thus, with the hope of Socrates contrast the confidence of Jesus.

Historic Christianity as a Corrective of Pietism.-Pietism is emotional Christianity, and considers a sudden, sensible, dateable, and stateable religious experience the indispensable beginning, and fluctuations of 
grace the proper staple of religious life. Pietism makes the Spirit's work fitful and arbitrary, and the power that works in us transcendent, immediate, mysterious and magical. It is most at home in the Fourth Gospel and the Epistles, and makes even the Lord's Prayer obsolete because it contains no reference to the atonement. Pietism really puts emotion above morality, while yet it opposes amusement and tends to asceticism. It is invariably censorious of others, while the peccadillos and even the sins of the coterie are viewed indulgently as designed to keep it humble. These our spiritual exquisites easily combine and easily separate again. Finally pietism shows ignorant impatience at delay in the sanctification both of the individual and the world. These pietist conceptions are not harmless, for they ever tend to breed self-deception or self-despair. The corrective lies in the synoptic gospels which make paramount an anti-Pharisaic and anti-ascetic morality, and teach growth in grace.

Four Types of Thought in the New Testament-The Type in the Synoptic GoSPELS.- The phrase Kingdom of God, or Kingdom of Heaven is characteristic here. Its meaning is given not by definition but only by discriminative use. Its Old Testament meaning is but a partial guide, for Jesus was in marked degree original. The surest guide to its meaning appears in the term Father as applied to God. As both concepts are fundamental they must coincide. This term Father likewise characterizes the synoptic gospels. Here all are children of God, while in the Fourth Gospel only certain believers are.

According to the synoptists Jesus accepts but does not parade the title of Christ. He prefers the title Son of Man, which he nowhere defines, but uses in the sense of the man, the brother and passionate lover of man. This title is absent from the epistles and is used in the Fourth Gospel in theological rather than ethical connotations. Worship is John's object, love that of the synoptists.

Finally the synoptists agree as to the experience of Jesus, who taught that this was no exception, since a godly life could not be lived without trouble. This truth forms the ethical basis of the passion. Paul regards the sufferings of Christ as sui generis. Christ's reply to Job's question, Why do the righteous suffer? is Just because they are righteous, in reaction from an ungodly world. Again, evil may be converted into good by acceptance, as lifting into a region of heroic joy. Lastly, cross-bearing is redemptive, whether in the case of Christ or Christians.

Paul's View of Christianity.-Paul was trained in Rabbinical learning and in Pharisaic practice. The Rabbinical God was a legislator and the relation of man to him was legal. When Paul became a Christian he taught contrariwise that God was a giver, and his theology attempts to formulate this view, sometimes, however, supporting it by Rabbinical arguments. The righteousness of God is the key-word to this theology, and is nowhere else in the New Testament used in the same sense, viz., the righteousness which God 
gives, an original and daring view. God is the Father of adopted and, therefore, unreal sons. Here the phraseology is legal, though the principle is antilegal. Romans, chap. 8 , shows how really Paul views the relation as vital. Paul's doctrine of sin is not vital to faith, and is much disputed. For example, the relation of Adam to man, the view that flesh is incurably bad, and that the law was meant only to irritate, find no support in the teaching of our Lord. I do not say they are wrong, but we can wait for further light. The now commonplace view that the Holy Spirit is the immanent source of Christian holiness was original with Paul when others regarded him as the source of miraculous powers.

Christianity according to the Epistle to the Hebrews. - The style and ideas show that Paul did not write this epistle and perhaps Apollos of Alexandria was its author, since a student of Philo meets familiar phrases in it. The central conception is nearness to God by Jesus as forerunner, in contrast with the distance observed under the Levitical law. Jesus is shown superior to prophets and angels, the agents of revelation, and to Moses and Aaron, the agents of redemption. Reference to the angels was concessive and not emphatic. Had the writer addressed us, he would probably have omitted them altogether. This superiority of Jesus is always based on his sonship. Thus with superiority in revelation, since a son has perfect intimacy with his father. So, as priest, the sonship of Jesus finds its type, not in Aaron but in Melchisedek who was a royal priest in virtue of dignity not ancestry. Then the relation of Christ as a son to the universe is stated. Here Philo may-but I think not-have influenced our writer. Jesus though divine could suffer, for glory and humiliation are not in absolute antithesis. Suffering is a privilege when it serves to help others. Again, the sufferings of Jesus served for discipline. This differs from Paul's view, and there is no use in trying to assimilate the two. But occasionally the sufferings of Jesus are said to be sacrificial. This sacrifice was eternal, that is, realized its ideal, and nothing better on the matter can be said.

The Type of Thought in the Fourth Gospel. - This gospel was written either by John or a disciple of John of the School at Ephesus. The synoptic gospels show Jesus as a man godlike, the Fourth Gospel as a god imperfectly manlike. And they report words as different as are the personalities. All admit difficulty in regarding both accounts as primary, and some conservative critics, as Watkins, in his Bampton Lecture, suppose the variation from the original to be in the Fourth Gospel. Provisionally accepting this view, let us study its theology as that of an Ephesian disciple. Analysis of the conception of Jesus given in the first eighteen verses of the book will reveal the writer's characteristics. There Jesus is represented as divine to whom it happened that he became flesh. This view exemplifies the trait of eternity. The entire absence of shading, as, e.g., between light and darkness, is an example of the other trait, absoluteness. Here is no progress, no birth, boyhood or growth in the eternal Christ who simply became flesh. The abso- 
luteness appears in the contrast between sons of God and sons of the Devil, between life and death, and the like. With this, contrast the moral discriminations between Pharisees and Publicans reported by the synoptists. This absolute moral judgment appears again in the saying, "All before me were thieves and robbers." This gives substantially the position of Christ, but the claim is expressed in unqualified terms where shading is needed. I think the lesson of the synoptists should be learned first, and I reject the view of Clement and some others that the Fourth Gospel reveals the heart of Christ, where the synoptists present only the exterior.

These two traits help to an understanding of the theology of the work. r. The Gospel is eternal life, which means life indeed and true, without distinctions of space, time, quality, or quantity, the same on earth and in heaven, not subject to growth, and sinless. But we know that such statements are true only of the divine ideal, and that in experience is a difference between now and then, etc.

2. The writer's conception of God is implied in the prevailing term, the Father, whereas the synoptists write your Father. Here the universal aspect is lacking. The sons of God are born not of blood. That God is good to all is not proclaimed.

3. In the doctrine of man no shading in moral judgment is observed. The dualism is so thoroughgoing as to suggest, though not to justify, the view that God could not have been the common creator of men. It resembles Manichean dualism so much that we cannot say the latter is not taught. This is Scylla, while minimizing moral distinctions is Charybdis.

4. The conception of Jesus is given in such expressions as, "I am the bread of life," and "I and the Father are one." These amount to a declaration that Jesus is sufficient for the religious need of man, and therefore is God. They may have been put into the mouth of Jesus, while really only the opinion of the writer drawn from the facts in the case.

5. The death of Jesus is regarded as the glorification of Jesus. The reference to a grain of wheat states that death in terms of natural law, and suggests a universal principle of which Christ's death was the highest case.

6. Entrance to life is made through the new birth, which is eternal and absolute. The sheep are all good, and never perish.

All this is noble, but I am thankful that it does not stand alone. It is too Alpine for constant residence. We must go to the synoptists to find one like us in all things, one only - sin-excepted. 